\title{
A distributed thermodynamic model for energy and mass balance computation: FEST-EWB
}

\author{
Chiara Corbari,* Giovanni Ravazzani and Marco Mancini \\ DIIAR, Politecnico di Milano, Piazza Leonardo da Vinci, 32, 20133 Milano, Italy
}

\begin{abstract}
:
This article presents the development of distributed thermodynamic model for energy and mass balance computation between soil surface and shallow atmospheric layers and its inclusion into the hydrological model FEST-EWB (Flash-flood Event-based Spatially distributed rainfall-runoff Transformation-Energy Water Balance). This model is also thought for a synergic use of hydrological model with remote sensing data. In particular, the energy budget is solved looking for the representative thermodynamic equilibrium temperature (RET) defined as the land surface temperature (LST) that closes the energy balance equation for any pixel of basin surface. So using this approach, through the system between the mass and energy equations, soil moisture (SM) is linked to the latent heat flux (LE) and then to LST. The RET thermodynamic approach solves most of the problems of the actual evapotranspiration (ET) and SM computation. In fact, it permits to avoid computing the effective ET as an empirical fraction of the potential one. This approach, based on the RET, has been tested at field scale (10 ha) with energy fluxes and LST measured with an eddy covariance station in Landriano (Italy). Copyright (C) 2010 John Wiley \& Sons, Ltd.
\end{abstract}

KEY WORDS energy water balance model; representative thermodynamic equilibrium temperature; land surface temperature; energy fluxes

Received 31 March 2010; Accepted 20 September 2010

\section{INTRODUCTION}

Hydrological models can give an important contribution to quantify mass and energy fluxes at the basin and irrigation district scale (Famiglietti and Wood, 1994; Montaldo and Albertson, 2001; Gurtz et al., 2002; Ravazzani et al., 2008; Rabuffetti et al., 2008).

Nevertheless, their application, both in operative and scientific research, is limited by the difficulties to verify evaporative fluxes and soil water content at the basin scale. In fact, calibration and validation of distributed models generally depend on comparison between simulated and observed discharges at the available rivers cross-sections.

Soil moisture (SM), which is recognized as the key variable in these hydrologic energy water balance models, respect to this role is most of the time confined to an internal numerical model variable (Dooge, 1986) and it seems that the link between internal variables of the processes [e.g. SM, land surface temperature (LST) and evapotranspiration (ET) fluxes] and external variables, which are the outputs of the model (e.g. discharge measurements), is not yet resolved. Consequently, the physically based distributed models risk to be still considered as 'Black-Box' models.

These problems drove the scientific community to the use of hydrologic modelling in conjunction with remote sensing data. In particular, there was a development of

\footnotetext{
* Correspondence to: Chiara Corbari, DIIAR, Politecnico di Milano, Piazza Leonardo da Vinci, 32, 20133 Milano, Italy.

E-mail: chiara.corbari@mail.polimi.it
}

distributed hydrological models with mass and energy balance equations ('Land surface model', LSM) for water content and ET estimations which use remote sensing data of LST, a connected variable to SM, as input parameters, validation terms or assimilation variables (Noihlan and Planton, 1989; Famiglietti and Wood, 1994; Anderson et al., 1997; Bastiaanssen et al., 1998; Montaldo and Albertson, 2001; Su, 2002; Corbari et al., 2008, 2010).

This approach based on LST seems to solve many limitations and difficulties of the previous technology based on micro-wave satellite images (Giacomelli et al., 1995; Mancini et al., 1999). In fact, promising results are now coming using both hydrological modelling and thermal infrared satellite images available from sensors like MODIS, ASTER and SEVIRI on board the main operative satellites (Anderson et al., 1997; Bastiaanssen et al., 1998; Minacapilli et al., 2009).

In particular, as stated by $\mathrm{Su}$ (2002) there exist three different types of energy balance models for ET estimates that use satellite and ground data as inputs: (1) residual approach, (2) to compute all the terms of the energy balance and (3) semi-empirical approach.

However, the models with a residual flux in the energy balance are more common in the scientific community and they can be subdivided into: (1) 'one-source' models that do not distinguish between evaporation and transpiration, such as the SEBAL model (Bastiaanssen et al., 1998) and the SEBS model (Su, 2002), that computes the latent heat flux (LE) as a residual term of the energy 
budget and (2) 'two-source' models that instead consider evaporation and transpiration separately, such as the TSEB model (Norman et al., 1995) where the LE is the residual or the FORCE-RESTORE model (Montaldo and Albertson, 2001) that computes the ground heat flux as a residual flux.

As stated by Kalma et al. (2008), the methods that compute all the terms of the energy balance are widely diffuse, but most of them are coupled with data assimilation techniques (e.g. LST from satellite data) to update the state variables. Instead, low efforts have been made to use LST for the calibration of some parameters of the models. Moreover, these models (e.g. VIC, Liang et al., 1994; or TOPLATS, Famiglietti and Wood, 1994) do not solve simultaneously the energy and mass balance equations.

In this context, this article has as objective the development of a thermodynamic model for energy and mass balance computation and its inclusion into the distributed hydrological model FEST-EWB (Flashflood Event-based Spatially distributed rainfall-runoff Transformation-Energy Water Balance) (Corbari, 2010). In particular, the approach of solving the energy budget between soil surface and shallow atmospheric layers looking for the defined LST that closes the energy balance equation in any pixel of the basin surface (hereafter called representative equilibrium temperature, RET) is developed for local scale as for large-scale use.

Particularly in this article, the validation of this new version of the FEST-EWB model is performed at local scale with ground measurements of LST and energy fluxes.

Future developments of this work will be the validation of the RET approach at basin scale by comparing in each pixel of the basin of the simulated RET (internal variable) with LST from satellite images together with the traditional calibration based on the comparison between simulated and observed discharges (external variable) at the control cross-sections of the rivers.

\section{THE DISTRIBUTED HYDROLOGICAL MODEL: FEST-EWB SCHEME}

FEST-EWB is a distributed hydrological energy water balance model (Corbari et al., 2008; Corbari, 2010) and it is developed starting from the FEST-EWB (Mancini, 1990; Rabuffetti et al., 2008; Ravazzani et al., 2008). FEST-EWB computes the main processes of the hydrological cycle: ET, infiltration, surface runoff, flow routing, subsurface flow and snow dynamics (Corbari et al., 2009). In the FEST-EWB, the energy balance module is introduced. The model is distributed so that the computation domain is discretized with a mesh of regular square cells in which every parameter is defined or calculated.

The variables of the model are listed in Table I including symbols, meanings and units of measurement.
Table I. List of symbols, their meaning and unit

\begin{tabular}{|c|c|c|}
\hline Symbol & Meaning & Unit \\
\hline$A$ & $\begin{array}{l}\text { Radiation reflected from } \\
\text { neighbouring terrain }\end{array}$ & - \\
\hline$B$ & Solar azimuth & - \\
\hline$C$ & $\begin{array}{l}\text { Angle between the sunbeam } \\
\text { direction and the perpendicular } \\
\text { to the ground }\end{array}$ & - \\
\hline$c_{\mathrm{b}}$ & Specific heat capacity of biomass & $\mathrm{J} \mathrm{kg}^{-1} \mathrm{~K}^{-1}$ \\
\hline$c_{\mathrm{p}}$ & Specific heat of humid air & $\mathrm{MJ} \mathrm{kg}^{-1} \mathrm{~K}^{-1}$ \\
\hline$c_{\mathrm{s}}$ & Specific heat capacity of soil & $\mathrm{J} \mathrm{kg}^{-1} \mathrm{~K}^{-1}$ \\
\hline$c_{\mathrm{w}}$ & Specific heat capacity of water & $\mathrm{J} \mathrm{kg}^{-1} \mathrm{~K}^{-1}$ \\
\hline$d$ & Zero plane displacement height & M \\
\hline DF & Scattered radiation & - \\
\hline$E$ & Mountain aspect & - \\
\hline$e^{*}$ & Saturation vapour pressure & $\mathrm{Pa}$ \\
\hline$e_{\mathrm{a}}$ & Vapour pressure & $\mathrm{Pa}$ \\
\hline ET & Evapotranspiration rate & $\mathrm{Mm}$ \\
\hline $\mathrm{FC}$ & Field capacity & - \\
\hline$f_{\mathrm{v}}$ & Vegetation fraction & - \\
\hline $\mathrm{F}_{-} \mathrm{CO}_{2}$ & Photosynthesis flux & $\mathrm{W} \mathrm{m}^{-2}$ \\
\hline$G$ & Soil heat flux & $\mathrm{W} \mathrm{m}^{-2}$ \\
\hline$g_{\text {term }}$ & Soil thermal conductivity & $\mathrm{W} \mathrm{m}^{-1} \mathrm{~K}^{-1}$ \\
\hline & Solar elevation angle & - \\
\hline$H_{\mathrm{s}}-H_{\mathrm{c}}$ & $\begin{array}{l}\text { Sensible heat fluxes for bare soil } \\
\text { (s) and for canopy (c) }\end{array}$ & $\mathrm{W} \mathrm{m}^{-2}$ \\
\hline$H_{\mathrm{w}}$ & Sensible heat flux over water & $\mathrm{W} \mathrm{m}^{-2}$ \\
\hline$I_{\mathrm{c}}$ & $\begin{array}{l}\text { Incoming solar radiation reaching } \\
\text { the ground in the normal } \\
\text { direction }\end{array}$ & - \\
\hline$I_{0}$ & $\begin{array}{l}\text { Extraterrestrial radiation at the top } \\
\text { of the atmosphere }\end{array}$ & - \\
\hline$k$ & Von Karman constant & - \\
\hline$K_{\mathrm{t}}$ & Fraction of scattered radiation & - \\
\hline$L$ & Obukhov length & $\mathrm{m}$ \\
\hline LAI & Leaf area index & - \\
\hline $\mathrm{LE}_{\mathrm{s}}-\mathrm{LE}_{\mathrm{c}}$ & $\begin{array}{l}\text { Latent heat fluxes for bare soil } \\
\text { (s) and for canopy (c) }\end{array}$ & $\mathrm{W} \mathrm{m}^{-2}$ \\
\hline LST & Land surface temperature & $\mathrm{K}$ \\
\hline $\mathrm{LE}_{\mathrm{w}}$ & Latent heat flux over water & $\mathrm{W} \mathrm{\textrm {m } ^ { - 2 }}$ \\
\hline$m_{\mathrm{b}}$ & Mass of biomass & $\mathrm{kg} \mathrm{m^{-2 }}$ \\
\hline$m_{\mathrm{w}}$ & Mass of water & $\mathrm{kg} \mathrm{m} \mathrm{m}^{-2}$ \\
\hline$p$ & $\begin{array}{l}\text { Reduction fraction for sky covered } \\
\text { with clouds }\end{array}$ & - \\
\hline$P$ & Precipitation rate & $\mathrm{Mm}$ \\
\hline PE & Drainage flux & $\mathrm{Mm}$ \\
\hline$Q$ & Direct radiation component & - \\
\hline$Q_{\mathrm{a}}$ & Actual direct radiation & - \\
\hline$r$ & Albedo & - \\
\hline$R$ & Runoff flux & $\mathrm{Mm}$ \\
\hline$R^{*}$ & $\begin{array}{l}\text { Theoretical radiation observed at } \\
\text { the ground level }\end{array}$ & - \\
\hline$r_{\mathrm{a}}$ & $\begin{array}{l}\text { Aerodynamic resistance for } \\
\text { vegetation }\end{array}$ & $\mathrm{s} \mathrm{m}^{-1}$ \\
\hline$r_{\mathrm{abs}}$ & $\begin{array}{l}\text { Aerodynamic resistance for bare } \\
\text { soil }\end{array}$ & $\mathrm{s} \mathrm{\textrm {m } ^ { - 1 }}$ \\
\hline$r_{\mathrm{c}}$ & Canopy resistance & $\mathrm{s} \mathrm{m}^{-1}$ \\
\hline RET & $\begin{array}{l}\text { Representative equilibrium } \\
\text { temperature }\end{array}$ & K \\
\hline RH & Air humidity & - \\
\hline
\end{tabular}

In Figure 1, the scheme of the complete hydrological model is reported. In particular, the input parameters of the model, surrounded by a rectangle with dashed lines, are: (1) the atmospheric forcings, such as air temperature, 
Table I. (Continued)

\begin{tabular}{|c|c|c|}
\hline Symbol & Meaning & Unit \\
\hline $\mathrm{Rn}$ & Net radiation & $\mathrm{W} \mathrm{m} \mathrm{m}^{-2}$ \\
\hline$R_{\mathrm{s}}$ & Incoming short-wave radiation & $\mathrm{W} \mathrm{m}^{-2}$ \\
\hline$r_{\mathrm{S}}$ & Soil resistance & $\mathrm{s} \mathrm{\textrm {m } ^ { - 1 }}$ \\
\hline$r_{\mathrm{s} \min }$ & Minimum stomatal resistance & $\mathrm{s} \mathrm{m}^{-1}$ \\
\hline$s$ & Atmosphere optical depth & - \\
\hline$s_{0}$ & $\begin{array}{l}\text { Optical depth at sea level (Kreider } \\
\text { and Kreith, 1975) }\end{array}$ & - \\
\hline$S_{\text {air }}$ & Air enthalpy changes & $\mathrm{W} \mathrm{m}^{-2}$ \\
\hline$S_{\text {canopy }}$ & Crop enthalpy changes & $\mathrm{W} \mathrm{m}^{-2}$ \\
\hline$S_{\text {soil }}$ & Soil surface layer heat flux & $\mathrm{W} \mathrm{m}^{-2}$ \\
\hline SM & Soil moisture & - \\
\hline$S_{\mathrm{w}}$ & Storage term of water & $\mathrm{W} \mathrm{m}^{-2}$ \\
\hline$T_{\mathrm{a}}$ & Air temperature & K \\
\hline$T_{\text {soil }}$ & $\begin{array}{l}\text { Temperature below the first layer of } \\
\text { soil } d z\end{array}$ & $\mathrm{~K}$ \\
\hline$u$ & Horizontal wind velocity & $\mathrm{m} \mathrm{s}^{-1}$ \\
\hline WP & Wilting point & - \\
\hline $\mathrm{WT}_{\text {prof }}$ & Water temperature at a fixed depth & $\mathrm{K}$ \\
\hline$z$ & Height above sea level & M \\
\hline$z_{\mathrm{oh}}$ & $\begin{array}{l}\text { Roughness length governing } \\
\text { transfer of heat and vapour }\end{array}$ & M \\
\hline$z_{\mathrm{h}}$ & Height of humidity measurements & M \\
\hline$z_{\mathrm{om}}$ & $\begin{array}{l}\text { Roughness length governing } \\
\text { momentum transfer }\end{array}$ & M \\
\hline$z_{\mathrm{m}}$ & Height of wind measurements & M \\
\hline$\alpha$ & Mountain slope & - \\
\hline$\gamma$ & Psychometric constant & $\mathrm{Pa}^{\circ} \mathrm{C}^{-1}$ \\
\hline$\eta$ & Nash and Sutcliffe index & - \\
\hline$\lambda$ & Latent heat of vapourization & MJ kg-1 \\
\hline$\xi_{\mathrm{c}}$ & Atmosphere emissivity & - \\
\hline$\xi_{\mathrm{s}}$ & Soil emissivity & - \\
\hline$\rho_{\mathrm{a}}$ & Air density & $\mathrm{kg} \mathrm{m}^{-3}$ \\
\hline$\rho_{\mathrm{s}}$ & Soil density & $\mathrm{kg} \mathrm{m}^{-3}$ \\
\hline$\rho_{\mathrm{w}}$ & Water density & $\mathrm{kg} \mathrm{m}^{-3}$ \\
\hline$\sigma$ & Stefan-Boltzmann constant & $\mathrm{W} \mathrm{m}^{-2} \mathrm{~K}^{-4}$ \\
\hline$\triangle \mathrm{RET}$ & Difference of RET in $\Delta t$ & - \\
\hline$\Delta t$ & Time step & $\mathrm{S}$ \\
\hline$\Delta T_{\mathrm{a}}$ & Difference of air temperature in $\Delta t$ & ${ }^{\circ} \mathrm{C}$ \\
\hline$\Delta T_{\text {soil }}$ & $\begin{array}{l}\text { Difference of soil temperature in } \\
\qquad \Delta t\end{array}$ & - \\
\hline$\Delta W / \Delta t$ & Energy storage terms & $\mathrm{W} \mathrm{m}^{-2}$ \\
\hline$\Delta z_{\text {air }}$ & $\begin{array}{l}\text { Height of the measurement } \\
\text { instrument of } T_{\mathrm{a}}\end{array}$ & $\mathrm{m}$ \\
\hline$\Delta z_{\text {soil }}$ & Soil heat flux plate depth & $\mathrm{m}$ \\
\hline$\Delta z_{\mathrm{w}}$ & Water depth & $\mathrm{m}$ \\
\hline$\psi$ & $\begin{array}{l}\text { Angle between the point with } \\
\text { maximum elevation in the } \\
\text { direction of the solar beam }\end{array}$ & - \\
\hline$\psi_{\mathrm{h}}$ & $\begin{array}{l}\text { Functions for atmospheric stability } \\
\text { governing transfer of heat and } \\
\text { vapour }\end{array}$ & - \\
\hline$\psi_{\mathrm{m}}$ & $\begin{array}{l}\text { Functions for atmospheric stability } \\
\text { governing momentum transfer }\end{array}$ & - \\
\hline
\end{tabular}

incoming short-wave radiation, wind velocity, precipitation, air humidity from ground stations, that need to be interpolated or from meteorological models, (2) the digital elevation model (DEM), (3) the soil parameters in distributed maps, such as the saturated hydraulic conductivity, the field capacity or the soil depth and (4) the vegetation parameters, such as leaf area index and vegetation height, which can be retrieved from ground or satellite

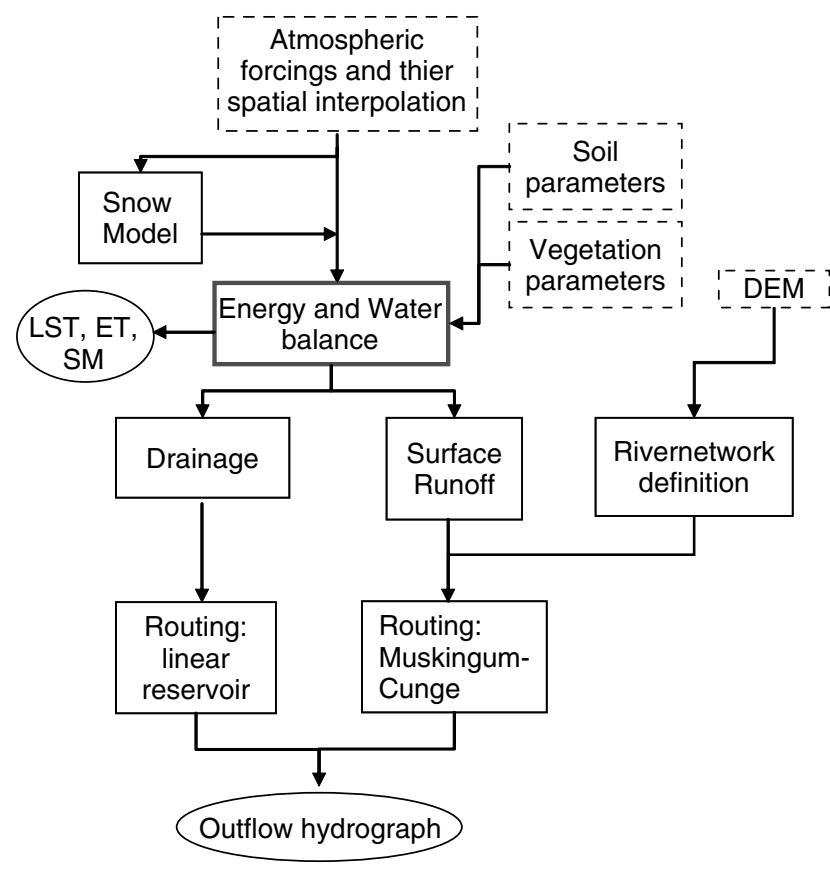

Figure 1. FEST-EWB scheme

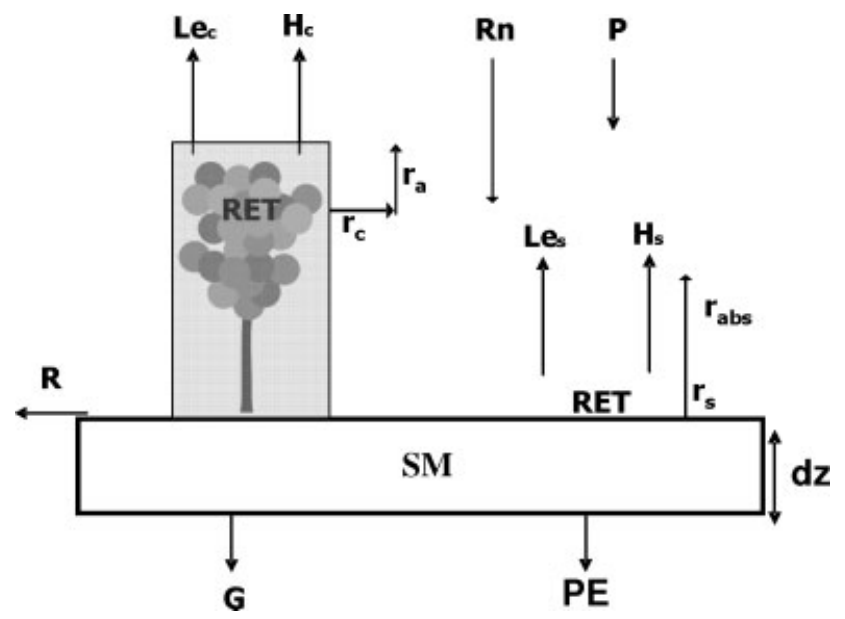

Figure 2. Energy and mass fluxes calculated in FEST-EWB

data. All the processes computed by the model are surrounded by a rectangle with continuous lines, while the outputs of the model, surrounded in Figure 1 by a circle, can be distributed values like LST and ET or/and local values, such as the discharge in the control cross-section of the river.

The core of the model is the system between the water and energy balance equations that are linked through ET. The terms of these equations are reported in Figure 2.

In particular, in the energy balance between soil surface, vegetation and low atmosphere, all the terms are computed and the equation is solved looking for the RET that is the LST that closes the energy balance equation.

So using this approach, SM is linked to the LE and then to RET. In fact, LE is computed as a function of the LST that closes the energy budget, but in addition the LE, as effective ET, is also a term of the mass balance equation which computes at every time step the 
evolution of SM. In fact, more SM is available in the soil, more ET is present, but also less energy is available for heating the surface. So through this system of energy and mass balance equations, LST variability can influence SM changes significantly.

Moreover, the RET thermodynamic approach solves most of the problems of the actual ET and SM computation. In fact, it permits the model to avoid computing the effective ET as an empirical function of potential ET, such as the beta function developed by Parlange et al. (1999).

\section{The water balance}

SM evolution for the generic cell at positions $i$ and $j$ is described by the water balance equation:

$$
\frac{\partial \mathrm{SM}_{i, j}}{\partial t}=\frac{1}{d z_{i, j}}\left(P_{i, j}-R_{i, j}-\mathrm{PE}_{i, j}-\mathrm{ET}_{i, j}\right)
$$

The water balance equation is computed in each cell of the domain characterized with a single layer of soil depth $d z$.

SM in cells covered by snow is assumed not varying with time.

\section{The energy balance}

Land surface energy balance is a reformulation of the first law of thermodynamics, which deals with the energy conservation where the total energy of a system remains the same even if energy transformations occur.

The complete energy balance equation at the ground surface for the generic cell at positions $i$ and $j$ is expressed as

$$
\begin{aligned}
& \mathrm{Rn}_{i, j}-G_{i, j}-\left(H_{\mathrm{s}}+H_{\mathrm{c}}\right)_{i, j}-\left(\mathrm{LE}_{\mathrm{s}}+\mathrm{LE}_{\mathrm{c}}\right)_{i, j} \\
& \quad=\frac{\Delta W}{\Delta t_{i, j}}
\end{aligned}
$$

These $\Delta W / \Delta t$ energy storage terms are often negligible, especially at basin scale with a low spatial resolution; instead at local scale the contribution of these terms could be significant (Meyers and Hollinger, 2004; Jacobs et al., 2008; Corbari, 2010).

The terms of the energy balance equation are described in the following section.

Net radiation. The net radiation is the algebraic sum of the incoming and outgoing short- and long-wave radiation:

$$
\mathrm{Rn}=R_{\mathrm{S}}(1-r)+\xi_{\mathrm{c}} \sigma\left(T_{\mathrm{a}}\right)^{4}-\xi_{\mathrm{s}} \sigma(\mathrm{RET})^{4}
$$

In literature, several equations exist for the description of the atmosphere emissivity, $\xi_{\mathrm{c}}$, considering clear and cloudy skies with different cloud cover fraction (Sedlar and Hock, 2009).

Short-wave net radiation, $R_{\mathrm{S}}(1-r)$, involved in the evaporative processes is calculated considering the effect of topography (Mancini et al., 2005). The radiation balance at basin surface varies with latitude, season, time

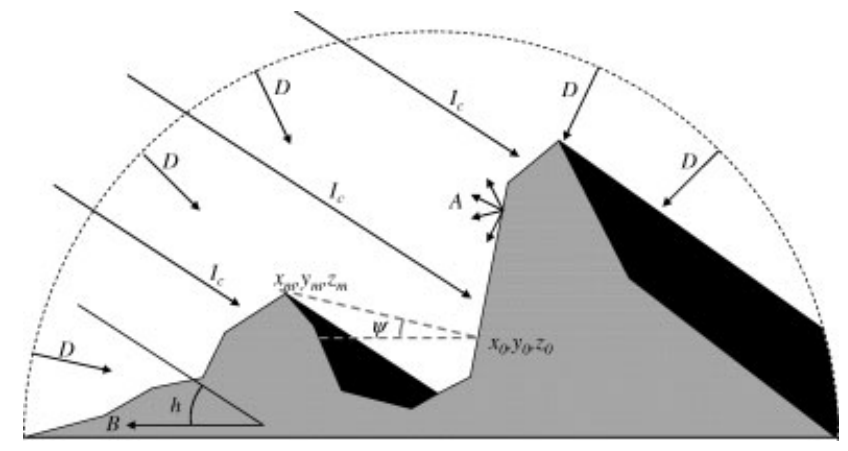

Figure 3. Radiation affected by topography

and presence of clouds; moreover, in mountain basins, topographic characteristics, such as slope and aspect, may have a relevant role. In fact, the topography affects the radiation field in three ways (Figure 3): (1) modulating the actual energy flux according to the relative position of the ground surface with respect to the sun, (2) reducing radiation because of shadowing effect of the higher ridges of mountains and (3) increasing net radiation by the fraction reflected from neighbouring terrains.

The incident short-wave radiation can be expressed as

$$
R_{\mathrm{s}}=Q_{\mathrm{a}}+\mathrm{DF}+A
$$

In clear sky conditions, the incoming solar radiation reaching the ground in the normal direction is

$$
I_{\mathrm{c}}=I_{0} \exp \left[\frac{-s}{\sin (h)}\right] \sin (h)
$$

where the atmosphere optical depth can be computed as $s=s_{0} P_{\mathrm{z}} / P_{0}$ and $P_{\mathrm{z}} / P_{0}$ is a correction factor that takes into account the difference in atmospheric pressure between sea level $\left(P_{0}\right)$ and actual elevation $\left(P_{\mathrm{z}}\right)$ :

$$
\frac{P_{\mathrm{z}}}{P_{0}}=\left(\frac{288-0 \cdot 0065 \cdot z}{288}\right)^{5.256}
$$

The scattered radiation for clear sky condition, $D$, is

$$
D=k_{\mathrm{b}}\left(I_{0} \sin (h)-I_{\mathrm{c}}\right)
$$

where $k_{\mathrm{b}}$ varies from 0.2 to 0.6 according to the sky brightness.

In clear sky condition, the theoretical radiation observed at the ground level is expressed by

$$
R^{*}=I_{\mathrm{c}}+D
$$

The presence of clouds or natural obstacles reduces the direct radiation $I_{\mathrm{c}}$ and modifies the scattered one so that $R^{*}$ can be reduced to a minimum fraction, $p$, of $\mathrm{R}^{*}$ (usually $p=0.22$ is referred to a transmissivity coefficient for $8 / 8$ stratocumulus cloud cover; Male and Granger, 1981). When the observed radiation is less than or equal to $p \times \mathrm{R}^{*}$, then the radiation is considered totally scattered (sky totally covered with clouds). Otherwise, the fraction of scattered radiation, $K_{\mathrm{t}}$, is computed as

$$
K_{\mathrm{t}}=\frac{R^{*}-R_{\mathrm{s}}}{\left[(1-p) R^{*}\right]}
$$


Finally, the component of the actual scattered radiation, $\mathrm{DF}$, can be computed as

$$
\mathrm{DF}=\min \left[R_{\mathrm{S}} \cdot D \cdot\left(1-K_{\mathrm{t}}\right)+R_{\mathrm{S}} \cdot K_{\mathrm{t}}\right]
$$

and the direct radiation component, $Q$, as

$$
Q=R_{\mathrm{s}}-\mathrm{DF}
$$

Direct radiation component, $Q$, is affected by topographic characteristics, such as slope, $\alpha$, and aspect, $E$. Actual direct radiation, $Q_{\mathrm{a}}$, is related to the sun elevation as

$$
Q_{\mathrm{a}}=\frac{Q \cos (C)}{\sin (h)}
$$

The angle (Figure 3) between the sunbeam direction and the perpendicular to the ground is evaluated as

$\cos (C)=\cos (h) \cdot \sin (\alpha) \cdot \cos (B-E)+\sin (h) \cdot \cos (\alpha)$ is

The radiation reflected from the neighbouring terrain

$$
A=Q_{\mathrm{a}} \cdot r \cdot\left(1-f_{\alpha}\right)
$$

where

$$
f_{\alpha}=1-\frac{\alpha}{180^{\circ}} .
$$

A module taking into account the shadow effect induced by topography was developed. The algorithm calculates the angle, $\psi$, between the point with maximum elevation in the direction of the solar beam, denoted by coordinates $x_{\mathrm{m}}, y_{\mathrm{m}}$ and $z_{\mathrm{m}}$, and the examined cell, denoted by coordinated $x_{0}, y_{0}$ and $z_{0}$ (Figure 3 ):

$$
\psi=\arctan \left[\frac{\left(z_{\mathrm{m}}-z_{0}\right)}{\sqrt{\left(x_{\mathrm{m}}-x_{0}\right)^{2}+\left(y_{\mathrm{m}}-y_{0}\right)^{2}}}\right]
$$

If $\psi$ is higher than the sun elevation, the cell is shadowed and the incident short-wave radiation is constituted by scattered component only:

$$
R_{\mathrm{S}}=\mathrm{DF}
$$

Soil heat flux. The soil heat flux is the heat changed for conduction with the subsurface soil and it is evaluated as

$$
G=\left(\frac{g_{\text {term }}}{d z}\right)\left(\operatorname{RET}-T_{\text {soil }}\right)
$$

The soil thermal conductivity, which depends on the soil water tension, is evaluated with the McCumberPielke equation that computes the soil water tension as a function of SM (McCumber and Pielke, 1981; PetersLidard et al., 1998).

Sensible heat flux. The sensible heat flux, which is heat energy transferred between the surface and air when their temperatures are different, is considered for bare soil, $H_{\mathrm{s}}$, and for vegetation, $H_{\mathrm{c}}$. The cell of the computational domain is characterized by a vegetation fraction, $f_{\mathrm{v}}$, to discriminate the percentage of vegetation coverage. The equation of this vertical flux is

$$
\begin{gathered}
H_{\mathrm{s}}+H_{\mathrm{c}}=\left(1-f_{\mathrm{v}}\right) \frac{\rho_{\mathrm{a}} c_{\mathrm{p}}}{r_{\mathrm{abs}}}\left(\operatorname{RET}-T_{\mathrm{a}}\right) \\
+f_{\mathrm{v}} \frac{\rho_{\mathrm{a}} c_{\mathrm{p}}}{r_{\mathrm{a}}}\left(\text { RET }-T_{\mathrm{a}}\right)
\end{gathered}
$$

The aerodynamic resistance regulates the transfer of heat and water vapour from the evapotranspirating surface into the air above the canopy. Correction functions for atmospheric stability or instability are included using the Thom model (Thom, 1975).

Aerodynamic resistance for vegetation fraction can be calculated using:

$$
r_{\mathrm{a}}=\frac{\left[\ln \left(\frac{z_{\mathrm{m}}-d}{z_{\mathrm{om}}}\right)-\Psi_{\mathrm{m}}\left(\frac{z_{\mathrm{m}}-d}{L}\right)\right]\left[\ln \left(\frac{z_{\mathrm{h}}-d}{z_{\mathrm{oh}}}\right)-\Psi_{\mathrm{h}}\left(\frac{z_{\mathrm{h}}-d}{L}\right)\right]}{k^{2} u}
$$

where $z_{\mathrm{m}}, d, z_{\mathrm{om}}, z_{\mathrm{h}}$ and $z_{\mathrm{oh}}$ are functions of the vegetation height. In case of bare soil condition, the aerodynamic resistance, $r_{\mathrm{abs}}$, should be calculated using the same Equation (19), but $z_{\mathrm{m}}, d, z_{\mathrm{om}}, z_{\mathrm{h}}$ and $z_{\mathrm{oh}}$ are calculated using vegetation height as the zero value.

Latent heat flux. The LE, which is the heat used in the phase change from a liquid to a gas, is considered for bare soil, $\mathrm{LE}_{\mathrm{s}}$, and for canopy, $\mathrm{LE}_{\mathrm{c}}$, and in the FEST-EWB is computed as

$$
\begin{aligned}
& \mathrm{LE}_{\mathrm{c}}+\mathrm{LE}_{\mathrm{s}}=f_{\mathrm{v}}\left(\frac{\rho_{\mathrm{a}} c_{\mathrm{p}}}{\gamma\left(r_{\mathrm{a}}+r_{\mathrm{c}}\right)}\right)\left(e^{*}-e_{\mathrm{a}}\right) \\
& +\left(1-f_{\mathrm{v}}\right) \frac{\rho_{\mathrm{a}} c_{\mathrm{p}}}{\gamma\left(r_{\mathrm{abs}}+r_{\mathrm{s}}\right)}\left(e^{*}-e_{\mathrm{a}}\right)
\end{aligned}
$$

The saturation vapour pressure, $e^{*}$, is computed as a function of the RET while the vapour pressure, $e_{\mathrm{a}}$, as a function of $T_{\mathrm{a}}$.

The canopy resistance, which describes the resistance of vapour flow through the transpiring crop, is expressed as (Jarvis, 1976)

$$
r_{\mathrm{c}}=\frac{r_{\mathrm{smin}}}{\mathrm{LAI}} \frac{(\mathrm{FC}-\mathrm{WP})}{(\theta-\mathrm{WP})}
$$

The soil resistance is the resistance at the evaporating soil surface (Sun, 1982) and is computed as

$$
r_{\mathrm{s}}=3.5\left(\frac{\theta_{\mathrm{sat}}}{\theta}\right)^{2.3}+33.5
$$

The latent heat of vapourization and the water density link the LE with the ET $\left(\mathrm{ms}^{-1}\right)$ as

$$
\mathrm{LE}=\lambda \rho_{\mathrm{w}} \mathrm{ET}
$$

Storage fluxes. The storage fluxes, which in literature have been demonstrated to be significant, can be calculated only when local scale simulations are performed where a micrometeorological station is available so that particular measurements are obtainable, such as the $\mathrm{CO}_{2}$ flux or values of air temperature at different height. 

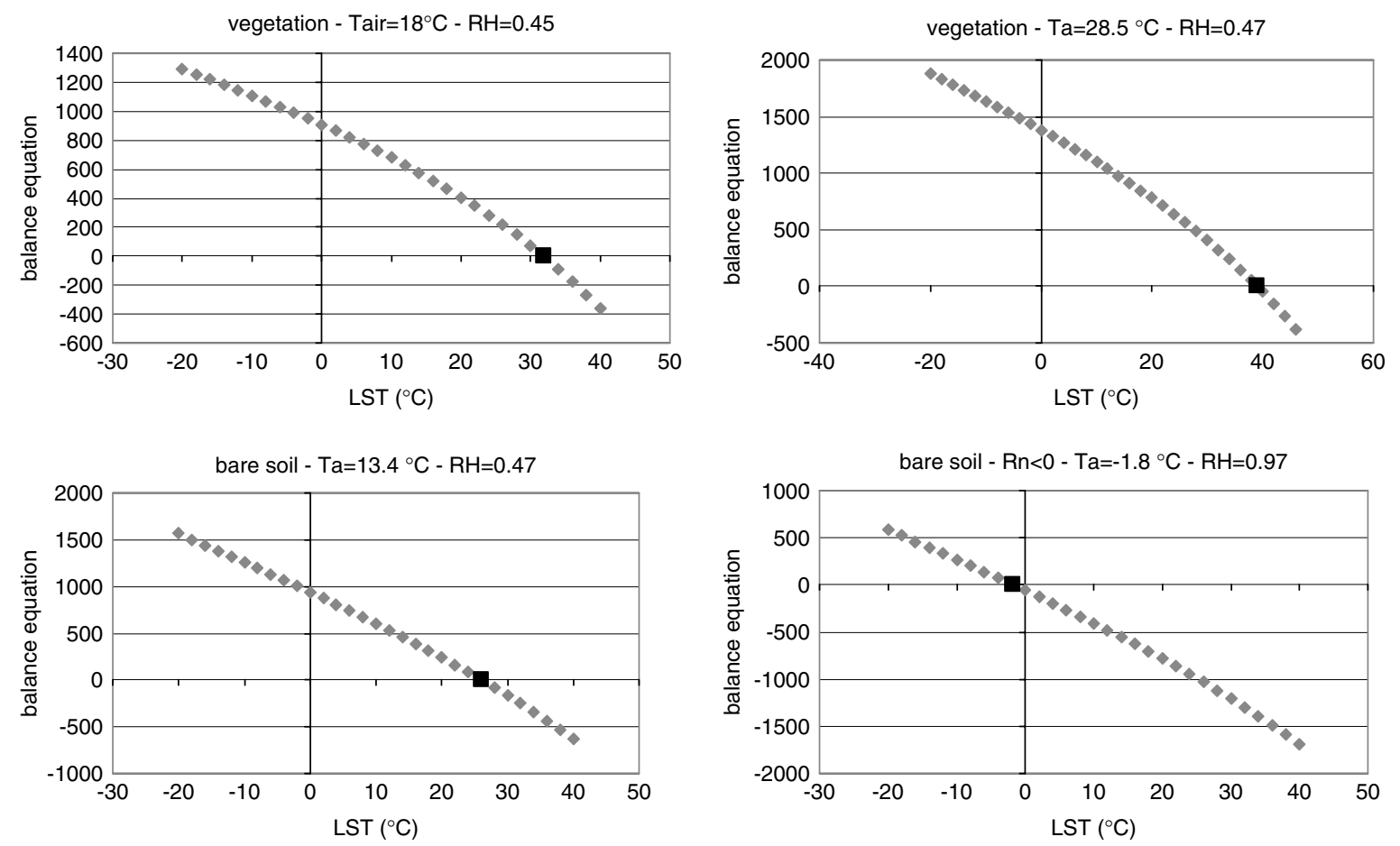

Figure 4. Shape of the complete energy balance equation solved with the Newton-Raphson method and the zero of the function

So if a local scale analysis is performed, the photosynthesis flux $\left(\mathrm{F}_{-} \mathrm{CO}_{2}\right)$, the crop and air enthalpy changes $\left(S_{\text {canopy }}\right.$ and $\left.S_{\text {air }}\right)$ and the soil surface layer heat flux $\left(S_{\text {soil }}\right)$ are the additional fluxes $\left(\mathrm{Wm}^{-2}\right)$ considered in the energy balance:

$$
\frac{\Delta W}{\Delta t_{i, j}}=\mathrm{F}_{-} \mathrm{CO}_{2 i, j}+S_{\mathrm{canopy} i, j}+S_{\mathrm{air} i, j}+S_{\mathrm{soil} i, j}
$$

The photosynthesis flux, that is the change in the Gibbs free energy, is calculated with the conversion from the measured flux of $1 \mathrm{mg} \mathrm{CO} \mathrm{m}^{-2} \mathrm{~s}^{-1}$ to $11 \mathrm{~W} \mathrm{~m}^{-2}$ (Nobel, 1974).

The air enthalpy is evaluated as

$$
S_{\text {air }}=\frac{\Delta T_{\mathrm{a}} \rho_{\mathrm{a}} c_{\mathrm{p}}}{\Delta t} \Delta z_{\text {air }}
$$

The canopy enthalpy is computed only over a fixed vegetation height:

$$
S_{\text {canopy }}=\frac{\Delta \operatorname{RET}\left(m_{\mathrm{w}} c_{\mathrm{w}}+m_{\mathrm{b}} c_{\mathrm{b}}\right)}{\Delta t}
$$

A similar approach is used for the heat flux in the soil surface layer:

$$
S_{\text {soil }}=\frac{\Delta T_{\text {soil }}\left(\mathrm{SM} m_{\mathrm{w}} c_{\mathrm{w}}+\rho_{\mathrm{s}} c_{\mathrm{s}}\right)}{\Delta t} \Delta z_{\text {soil }}
$$

This soil energy flux is the same term that is added in the post-processing of the analysed data to the soil heat flux measured by a heat flux plate.

Solution scheme. All the terms of the energy budget, as seen in the precedent sections, depend on RET and so the energy balance equation can be solved looking for the RET that closes the equation with the well known Newton-Raphson method. The iterative procedure implemented in the FEST-EWB model is

$$
\mathrm{LST}_{n}=\mathrm{LST}_{n-1}+\frac{f_{\mathrm{t}}\left(\mathrm{LST}_{n-1}\right)}{f_{\mathrm{t}}^{\prime}\left(\mathrm{LST}_{n-1}\right)}
$$

where $\mathrm{LST}_{n}$ is the actual value, $\mathrm{LST}_{n-1}$ the value at the previous iteration, $f_{\mathrm{t}}\left(\mathrm{LST}_{n-1}\right)$ the energy balance function and $f_{\mathrm{t}}^{\prime}\left(\mathrm{LST}_{n-1}\right)$ its derivative. The solution is acceptable when $\left|\frac{f_{\mathrm{t}}(\mathrm{LST})}{f_{\mathrm{t}}^{\prime}(\mathrm{LST})}\right|<$ tolerance and $f_{\mathrm{t}}(\mathrm{LST})<$ tolerance, with tolerance equal to $0 \cdot 001$.

The Newton-Raphson method is the best known method for finding successively better approximations to the zeros of a function and it converges often quickly, especially if the iteration begins sufficiently near the solution. For the correct interpretation of the mathematical results of the method, the shape of the complete energy balance equation has been analysed. Different possible atmospheric and soil coverage conditions have been considered and the function always has only one zero. In the following text, the energy balance equation versus LST is reported for daily values in a bare soil condition and in a vegetative period and for night values in a bare soil condition (Figure 4).

Energy balance equation for water surface. For water bodies, such as lake or paddy, the energy water balance equation is introduced and is solved, as for the soil surface energy budget, with the Newton-Rhapson method:

$$
\mathrm{Rn}-H_{\mathrm{w}}-\mathrm{LE}_{\mathrm{w}}=S_{\mathrm{w}}
$$



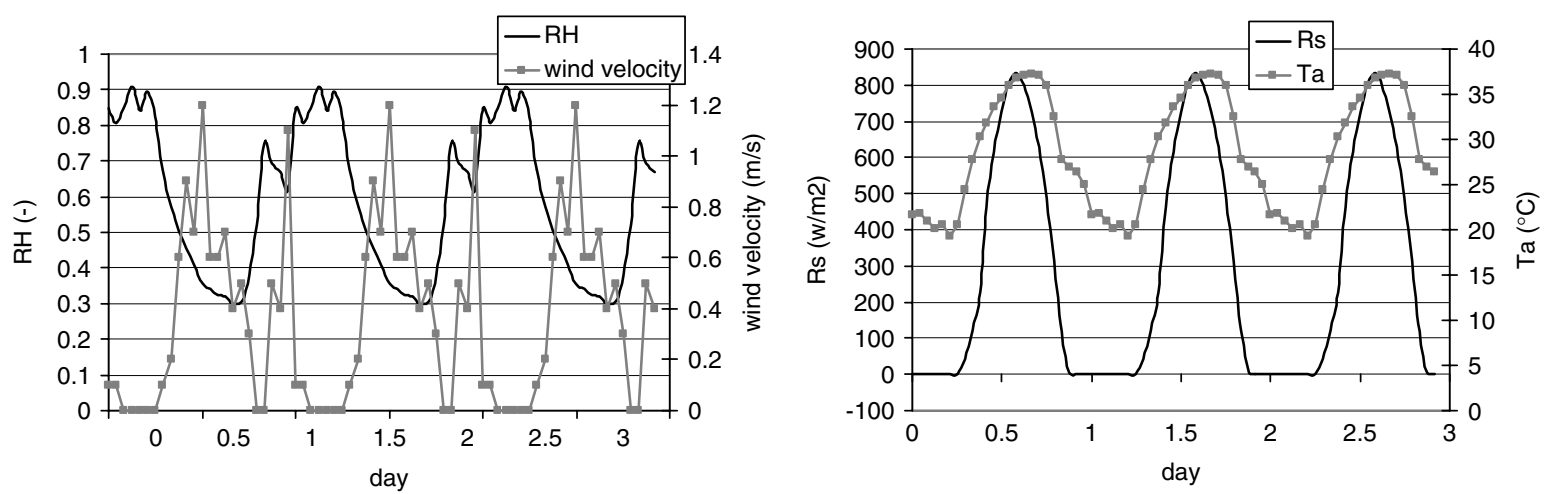

Figure 5. Meteorological variables used as input into the model

The LE is considered in its potential form, while $G$ $\left(\mathrm{W} \mathrm{m} \mathrm{m}^{-2}\right)$ is often negligible. The storage term of water is computed as

$$
S_{\mathrm{w}}=\frac{\left(\mathrm{LST}-\mathrm{WT}_{\mathrm{prof}}\right) \rho_{\mathrm{w}} c_{\mathrm{w}}}{\Delta t} \Delta z_{\mathrm{W}}
$$

\section{SYNTHETIC TEST CASES}

Synthetic test cases are presented to show the functioning of the RET approach at local scale. A data set of meteorological conditions is created by repeating single day's measurements of incoming short-wave radiation $\left(R_{\mathrm{S}}\right)$, air humidity $(\mathrm{RH})$, wind velocity $(u)$ and air temperature $\left(T_{\mathrm{a}}\right)$. This data set is reported in Figure 5. During the simulations the rain $(P)$ is set to zero.

Four different cases for bare soil and vegetation with different SM conditions are considered: (1) bare soil with SM set as initial condition equal to $0 \cdot 4$, (2) bare soil with SM equal to $0 \cdot 18$ (3) vegetation of 2-m height with SM equal to 0.4 and (4) vegetation of $2-\mathrm{m}$ height with SM equal to $0 \cdot 18$.

In Figure 6, the energy fluxes (e.g. net radiation, latent and sensible heat fluxes and soil ground heat flux), LST and SM are reported for each test case. In particular, the difference between bare soil and vegetation is correctly visible. In fact for the two bare soil cases 1 and 2 , the sensible heat flux is predominant on the LE, while it is the opposite in both the vegetation cases 3 and 4. Moreover, if the LST is considered, in both the bare soil cases the daily peak of LST is higher than in both the vegetation cases of about $10^{\circ} \mathrm{C}$.

Instead looking only at vegetation conditions, case 4 has lower soil water content than case 3 which corresponds to a lower LE, a higher LST and consequentially a higher sensible heat flux. These results can also be found from the comparison between bare soil case 2 with lower SM initial state and case 1 with higher SM.

\section{MODEL VALIDATION AGAINST OBSERVED DATA}

FEST-EWB model based on the RET approach can now be validated using LST measured by ground radiometer in any pixel of the analysis domain.
In this article, the model is validated at the study site of Landriano (Italy), an experimental field of maize, where an eddy covariance station has been positioned for monitoring energy and mass exchanges. In particular, the considered data set is composed of LST and net radiation measured from the CNR1 by Kipp and Zonen radiometer, latent and sensible heat fluxes are computed from the covariance between the vertical wind velocity and the relative air humidity and the air temperature measured from the sonic anemometer (Young 81000 by Young) and the gas analyser (LICOR 7500 by LICOR), while the ground heat flux is measured by two thermocouples ELSI and a heat flux plate (HFP01 by Hukseflux). These data are recorded at 30-min time step from 13 March 2006 to 11 October 2006, when the maize was harvested. Maize was planted on 1 June 2006.

The validation process is based on the comparison between the simulated energy fluxes and LST and the measured ones by the micrometeorological station. More details about Landriano eddy covariance stations, its entire instrumentation, its data set and the analysis on the quality of the measured data can be found in Corbari (2010).

\section{Energy fluxes}

The measured fluxes are compared with the simulated ones and a good accuracy is reached for the net radiation and the latent and sensible heat fluxes. Instead, the soil heat flux is reproduced in disagreement with the observed data due to representativeness problem of the measured $G$ (Kustas et al., 2000) (Figure 7). These results are also confirmed from a statistical analysis (Table II) looking for the minimization of the root mean square error (RMSE) and the maximization of the efficiency of the Nash and Sutcliffe index, $\eta$ (Nash and Sutcliffe, 1970).

In Table II, the angular coefficients of the linear regression curves between simulated and observed energy fluxes and their $R^{2}$ are also reported. Also, the cumulated fluxes are well reproduced.

\section{LST from ground data}

LSTs measured from the radiometer at the eddy covariance station are compared with RETs simulated from FEST-EWB and a mean difference over the entire 

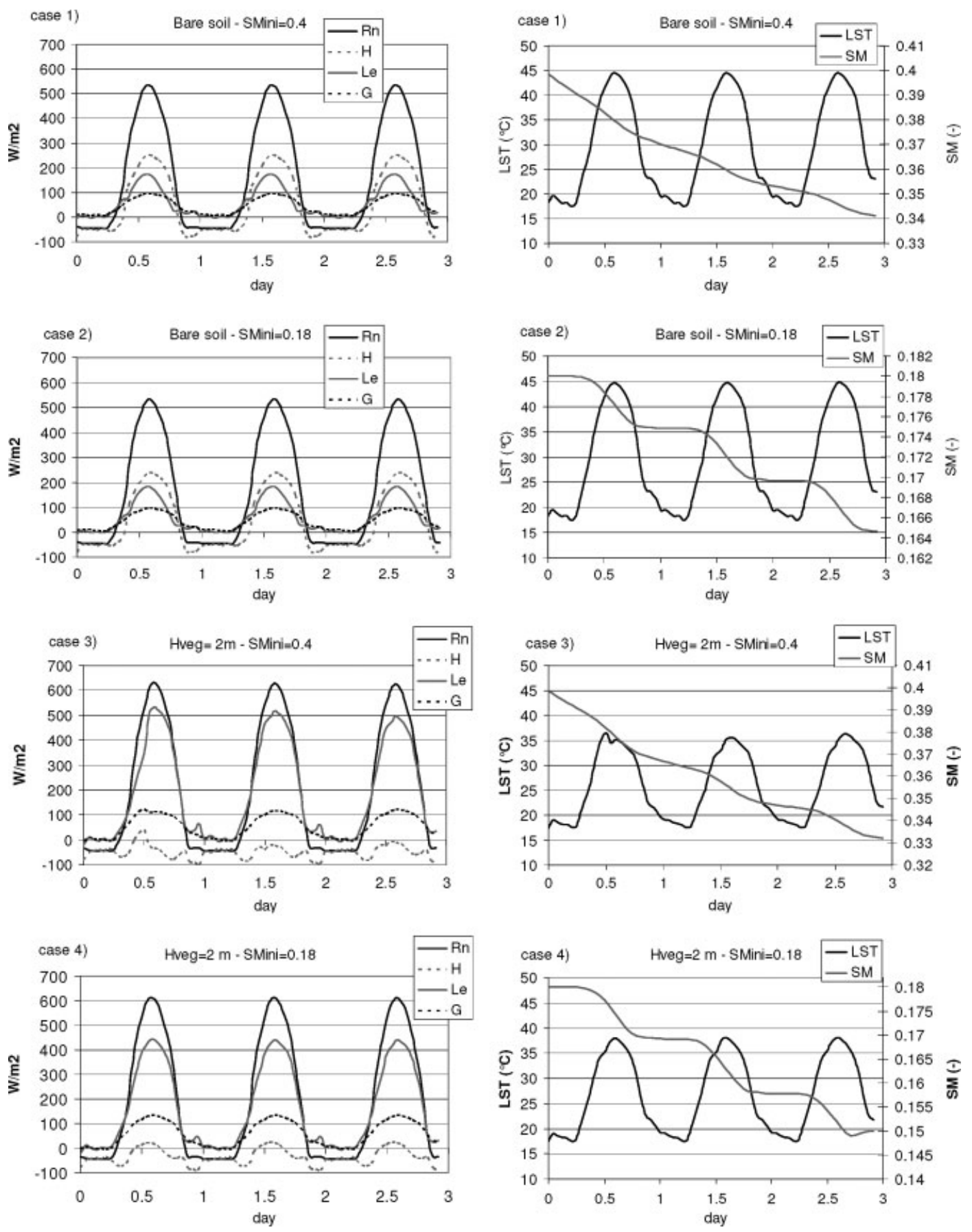

Figure 6. Test cases for bare soil and vegetation with different SM conditions

period of simulation of $-0.7^{\circ} \mathrm{C}$ is reached. In Table II, some statistical results are reported, confirming the good capability of the model in reproducing observed LSTs. In Figure 8, the scatter plots between the simulated RET and the observed LST are reported showing similarity between the two variable values.

\section{CONCLUSIONS}

This article presented an approach for energy water balance computation based on the thermodynamic equilibrium implemented in a distributed hydrological model FEST-EWB for a synergic use of hydrological model with remote sensing and ground data. The energy budget is solved looking for the representative thermodynamic equilibrium temperature, RET, defined as the LST that closes the energy balance equation for any pixel of basin surface.

The energy approach method based on the RET temperature seems to provide consistent results for vegetated and non-vegetated areas. In fact, the synthetic test cases showed the correct functioning of the model for different conditions. Moreover, the comparison between observed LST from ground radiometer at Landriano station and simulated RET confirms the goodness of the approach and a good capability in representing the observed data 

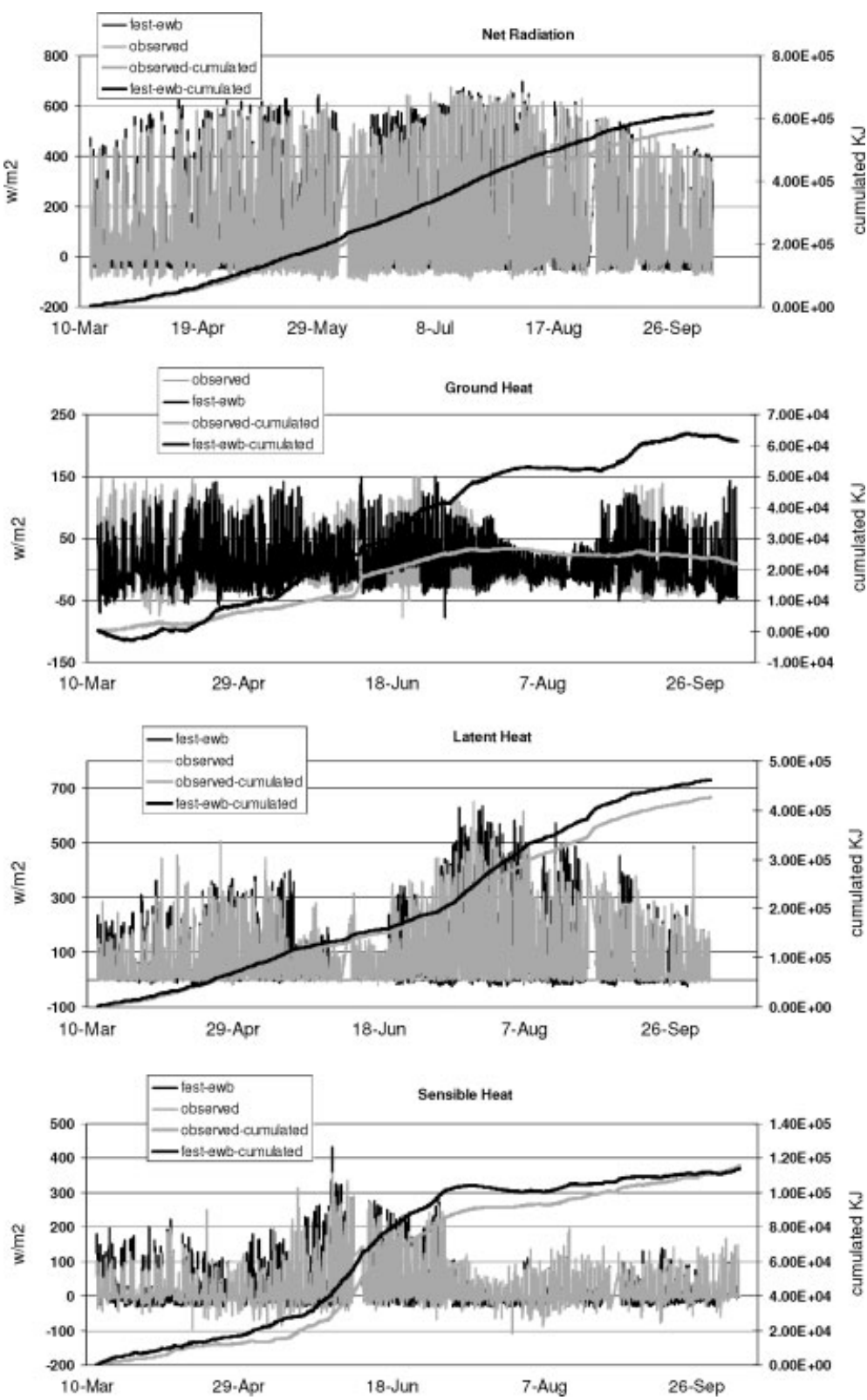

Figure 7. Comparison between the simulated and measured energy fluxes

Table II. RMSE, the Nash and Sutcliffe index, the angular coefficient of the linear regression and the errors on the cumulated total energy for the energy fluxes and LST

\begin{tabular}{lccccc}
\hline & $\eta$ & RMSE & $\begin{array}{c}\text { Angular } \\
\text { coefficient }\end{array}$ & $R^{2}$ & $\begin{array}{c}\text { Total energy } \\
(\%)\end{array}$ \\
\hline Rn & 0.96 & 38.3 & $y=0.95 x$ & 0.97 & 2.4 \\
LE & 0.75 & 54.8 & $y=0.87 x$ & 0.70 & 3.4 \\
$H$ & 0.71 & 29.6 & $y=0.80 x$ & 0.66 & -1.3 \\
$G$ & 0.68 & 22.5 & $y=0.84 x$ & 0.80 & 7.2 \\
LST & 0.87 & $3.2\left({ }^{\circ} \mathrm{C}\right)$ & $y=0.98 x$ & 0.89 & - \\
\hline
\end{tabular}

is also shown with the comparison between the modelled and observed energy fluxes at the eddy covariance station.

The possibility given by this approach to compare observed LST in a quantitative way from ground radiometers and computed from model offers the possibility to test this model in the future over larger area

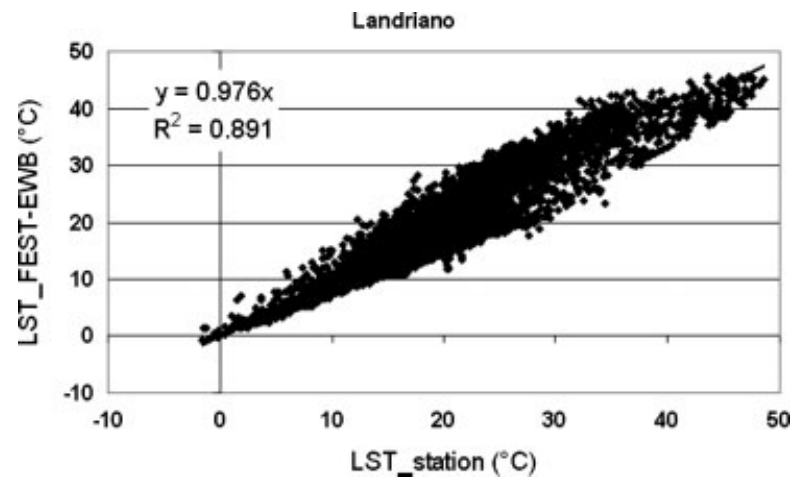

Figure 8. Comparison between the simulated and the observed LST

validating it with LST from satellite images. Moreover, this way of modelling the soil water balance seems to solve the problems of controlling the hydrological models only with external variable, such as discharge. In fact, 
the computation of LST at pixel scale can be considered as an increase of points where fluxes can be controlled in addition to the traditional gauges stations at the basin outlet.

\section{ACKNOWLEDGEMENTS}

This work was developed in the framework of the ACQWA EU/FP7 project (grant number 212250) 'Assessing Climate impacts on the Quantity and quality of WAter', of the Azioni Integrate Italia-Spagna (20092010) project (prot. IT09G9BLE4) 'Land Surface temperature from remote sensing for operative validation of an hydrologic energy water balance model', supported by the Italian Ministry of University and Scientific Research and the ACCA project funded by Regione Lombardia in collaboration with the University of Milan 'Misura e modellazione matematica dei flussi di ACqua e CArbonio negli agro-ecosistemi a mais'. The authors wish to thank the reviewers for comments and suggestions.

\section{REFERENCES}

Anderson MC, Norman JM, Diak GR, Kustas WP, Mecikalski JR. 1997. A two-source time-integrated model for estimating surface fluxes using thermal infrared remote sensing. Remote Sensing of Environment 60: 195-216.

Bastiaanssen WGM, Menenti M, Feddes RA, Holtslag AAM. 1998. A remote sensing surface energy balance algorithm for land (SEBAL), 1. Formulation. Journal of Hydrology 212-213: 198-212.

Corbari C. 2010. Energy water balance and land surface temperature from satellite data for evapotranspiration control. $\mathrm{PhD}$ thesis, Politecnico di Milano, Milan, Italy.

Corbari C, Horeschi H, Ravazzani G, Mancini M. 2008. Land Surface Temperature from Remote Sensing and from an Energy Water Balance Model for Irrigation Management. Options Méditerranéennes, Series A (Mediterranean Seminars). CIHEAM: Bari; 223-234.

Corbari C, Ravazzani G, Martinelli J, Mancini M. 2009. Elevation based correction of snow coverage retrieved from satellite images to improve model calibration. Hydrology and Earth System Sciences 13: 639-649 (www.hydrol-earth-syst-sci.net/13/639/2009).

Dooge JCI. 1986. Looking for hydrologic laws. Water Resources Research 22(9): 46-58.

Famiglietti JS, Wood EF. 1994. Multiscale modelling of spatially variable water and energy balance processes. Water Resources Research 30: 3061-3078.

Giacomelli A, Bacchiega U, Troch P, Mancini M. 1995. Evaluation of surface soil moisture by means of SAR remote sensing techniques and conceptual modelling. Journal of Hydrology 166: 445-459.

Gurtz J, Jasper K, Lang H. 2002. Advanced flood forecasting in Alpine watershed by coupling meteorological and forecasts with a distributed hydrological model. Journal of Hydrology 267: 40-52.

Jacobs AFG, Heusinlveld BG, Holtslag AAM. 2008. Towards closing the energy surface budget of a mid-latitude grassland. Boundary Layer Meteorology 126: 125-136.

Jarvis PG. 1976. The interpretation of the variations in leaf water potential and stomatal conductance found in canopies in the field. Philosophical Transactions of the Royal Society of London, Series B 273: 593-610.

Kalma JD, McVicar TR, McCabe MF. 2008. Estimating land surface evaporation: a review of methods using remotely sensed surface temperature data. Surveys in Geophysics 29: 421-469.

Kreider JF, Kreith F. 1975. Solar Heating and Cooling: Engineering, Practical Design, and Economics. McGraw-Hill: New York.

Kustas WP, Prueger JH, Hatfieldb JL, Ramalingamc K, Hippsc LE. 2000. Variability in soil heat flux from a mesquite dune site. Agricultural and Forest Meteorology 103: 249-264.
Liang X, Lettenmaier DP, Wood EF, Burges SJ. 1994. A simple hydrologically based model of land surface water and energy fluxes for GCMs. Journal of Geophysical Research 99: 14 415-14 428.

Male DH, Granger RJ. 1981. Snow surface energy exchange. Water Resources Research 17(3): 609-627.

Mancini M. 1990. La modellazione distribuita della risposta idrologica: effetti della variabilità spaziale e della scala di rappresentazione del fenomeno dell'assorbimento. PhD dissertation, Politecnico di Milano, Milan (In italian).

Mancini M, Hoeben R, Troch P. 1999. Multifrequency radar observation of bare surface soil moisture content: a laboratory experiment. Water Resources Research 35: 1827-1838.

Mancini M, Martinelli J, Ravazzani G. 2005. A distributed model based on energy balance equation for the simulation of hydrologic cycle at the basin scale. In Rendiconti Cremonesi-Il contributo del Politecnico di Milano alla Conoscenza delle Dinamiche Evolutive nel Territorio di Cremona, Paolillo PL (ed). CLUP: Milan; 201-213 (In italian).

McCumber MC, Pielke RA. 1981. Simulation of the effects of surface fluxes of heat and moisture in a mesoscale numerical model. Journal of Geophysical Research 86(C10): 9929-9938.

Meyers TP, Hollinger SE. 2004. An assessment of storage terms in the surface energy balance of maize and soybean. Agricultural and Forest Meteorology 125: 105-115.

Minacapilli M, Agnese C, Blanda F, Cammalleri C, Ciraolo G, D’Urso G, Iovino M, Pumo D, Provengano G, Rallo G. 2009. Estimation of actual evapotranspiration of Mediterranean perennial crops by means of remote-sensing based surface energy balance models. Hydrology and Earth System Sciences 13: 1061-1074 (www.hydrol-earth-syst-sci.net/13/1061/2009).

Montaldo N, Albertson JD. 2001. On The Use of the Force-Restore SVAT model formulation for stratified soils. Journal of Hydrometeorology 2(6): $571-578$.

Nash JE, Sutcliffe JV. 1970. River flow forecasting through the conceptual models, Part 1: A discussion of principles. Journal of Hydrology 10(3): 282-290.

Nobel PS. 1974. Introduction to Biophysical Plant Physiology. Freeman: New York.

Noihlan J, Planton S. 1989. A Simple parameterization of Land Surface Processes for Meteorological Models. Monthly Weather Review 117: $536-549$.

Norman JM, Kustas WP, Humes KS. 1995. Source approach for estimating soil and vegetation energy fluxes in observations of directional radiometric surface temperature. Agricultural and Forest Meteorology 77: 263-293.

Parlange MB, Albertson JD, Eichinger WE, Cahill AT, Jackson TJ. 1999. Evaporation: use of fast-response turbulence sensors, Raman Lidar, and passive microwave remote sensing. In Vadose Zone Hydrology: Cutting Across Disciplines, Parlange MB, Hopmans JW (eds). Oxford University Press: 454.

Peters-Lidard CDP, Blackburn E, Liang X, Wood EF. 1998. The effect of soil thermal conductivity parameterization on surface energy fluxes and temperatures. Journal of the Atmospheric Sciences 55: 1209-1224.

Rabuffetti D, Ravazzani G, Corbari C, Mancini M. 2008. Verification of operational Quantitative Discharge Forecast (QDF) for a regional warning system - the AMPHORE case studies in the upper Po River. Natural Hazards and Earth System Sciences 8: 161-173.

Ravazzani G, Rabuffetti D, Corbari C, Mancini M. 2008. Validation of FEST-WB, a continuous water balance distributed model for flood simulation. Proceedings of XXXI Italian Hydraulic and Hydraulic Construction Symposium. Perugia.

Sedlar J, Hock R. 2009. Testing longwave radiation parameterizations under clear and overcast skies at Storglaciaren, Sweden. The Cryosphere 3: 75-84 (www.the-cryosphere.net/3/75/2009/).

Su Z. 2002. The Surface Energy Balance System (SEBS) for estimation of turbulent heat fluxes. Hydrology and Earth System Sciences 6(1): $85-99$.

Sun SF. 1982. Moisture and heat transport in a soil layer forced by atmospheric conditions. M.Sc. Thesis, University of Connecticut, Storrs, CT.

Thom AS. 1975. Momentum, mass and heat exchange of plant communities. In Vegetation and Atmosphere, Monteith JL (ed). Academic Press: London; 57-110. 